\title{
RELIGIOUS EDUCATION AND EMPOWERMENT: Study on Pesantren in Muslim Minority West Papua
}

\author{
Ismail Suardi Wekke \\ Sekolah Tinggi Agama Islam Negeri Sorong \\ Jl. Klamono-Sorong, KM. 17, Klablim, Sorong, West Papua, 98417 \\ e-mail: iswekke@gmail.com
}

\begin{abstract}
Abstrak: Pendidikan Islam dan Pemberdayaan: Studi Kasus Pesantren pada Muslim Minoritas Papua Barat. Pendidikan Islam Indonesia merupakan salah satu pilar pendidikan nasional yang memiliki sejarah panjang. Dalam dinamika pembangunan, pesantren kembali membuktikan diri sebagai elemen penting bangsa. Tulisan ini membahas aktivitas dan gerakan madrasah di daerah minoritas Muslim dalam upaya membangun kapasitas umat melalui pembelajaran kewirausahaan. Penelitian ini dilaksanakan dengan menggunakan pendekatan kualitatif dengan ragam studi kasus. Observasi dan wawancara diterapkan untuk mengumpulkan data. Penulis menemukan adanya pelatihan dan pembelajaran berbasis kebutuhan mendorong siswa untuk menekuni keterampilan untuk aktivitas sehari-hari. Pesantren Roudhotul Khuffadz mengembangkan pola pembelajaran dengan mengacu kepada lingkungan peserta didik. Disimpulkan bahwa pendidikan Islam dengan tumpuan pada kebutuhan dan kepedulian akan lingkungan dapat memberdayakan santri untuk penguasaan keterampilan, walaupun itu dilaksanakan dengan keterbatasan komunitas di wilayah minoritas Muslim.
\end{abstract}

\begin{abstract}
Islamic education in Indonesia is one pilar in national education whis has a long history. In the course of time with development dynamics, pesantren (Islamic boarding school) proves as a nation-wide important element. Therefore, this paper will explore dicsuccion on activity and madrasah movement in Muslim minority in term capacity building through enterprenurship learning. This study was employed qualitative approach with miscellaneous case study. Observation and in-depth interview were conducted on collecting data. This research shows that daily-need based training and learning encourages students to enhance their skills during day after day activities. Pesantren Roudhatul Khuffadz enlarges learning cycle according to students' environment. Finally, it can be concluded that Islamic education can develop students' skill acquicition, although it is practiced with community limitation in Muslim minority area.
\end{abstract}

Keywords: pesantren, religious education, Muslim minority, West Papua 


\section{Introduction}

Wang discoveres that education is a means to pass down values, which will in turn become the aid and determinant in everyday human life and at the same time, will improve the fate and civilization of man. ${ }^{1}$ Without education, it is certain that today's generation will be no different from the generation of the past, whereby when compared, we are so different in opinion and practice, whether in term of quality of life or even the process of empowerment. Another fact, although rather extreme, that the progress and regression or good and bad of a civilization and nation will be determined by the education employed by that civilization and nation. ${ }^{2}$ This proves that education is indeed a process of transformation for civilizations between generations. Through this space, pesantren (Islamic boarding school) contributes to the nation. Genç, Avest and Miedema presented regarding religion in education, the most remarkable points of religious education respect to both state schools as well as denominational schools respectively in the form of teaching about worldviews. ${ }^{3}$

In this era of the $21^{\text {st }}$ century, an Islamic education approach is taken through operational processes toward desired goals, needing a consistent model that can support the moral-spiritual and intellectual values that underline them. From the history of the Prophet Muhammad SAW., these values can be actualized based on the needs and development of man, together with current cultural influences. Therefore, aspirations and purpose to elevate quality of life in all aspects of life can be achieved. Elyas and Picard shows that education indicates a direct link between teaching practices and the current processes that construct understanding. ${ }^{4}$ However, the reality of Islamic education nowdays is disappointing and can even be assessed as outdated. All this lies in the weaknesses within it. The flaw of Islamic education lies mainly in its concept, system and curriculum. ${ }^{5}$ It is beginning to be seen as less relevant in the development of today's civilization or it cannot be paired with other discipline of knowledge relevant to the community's requirements.

The reality at this moment, Islamic education is classified as yet to satisfactorily be

${ }^{1}$ Qiyun Wang, "A Generic Model for Guiding the Integration of ICT into Teaching and Learning," in Innovations in Education and Teaching International, Vol. XLV, No. 4 (November 2008), p. 411-419.

${ }^{2}$ Anwar Arifin, Format Baru Pengelolaan Pendidikan (Jakarta: Pustaka Indonesia, 2006), p. 115.

${ }^{3}$ M. Fatih Genç, Ina ter Avest, and Siebren Miedema, "Religious Education in Two Secular Multicultural Societies: the Turkish and Dutch Case Compared," in Procedia Social and Behavioral Sciences, 15, (2011), p. $801-805$.

${ }^{4}$ Tariq Elyas and Michelle Picard, "Saudi Arabian Educational Histori: Impacts on English Language Teaching," in Education, Business and Society: Contemporary Middle Eastern Issues, Vol. III, No. 2, (2010), p. $136-145$.

${ }^{5}$ The curriculum is always changing from one year to the next, so much so that educators are only confused by the changes. See Muhaimin, Pengembangan Kurikulum Pendidikan Agama Islam: di Sekolah, Madrasah, dan Perguruan Tinggi (Jakarta: RajaGrafindo Persada, 2005), p. 10. 
implemented and produce desired outcome. One of the innovations is teaching foreign language as a tool to enhance students' skill in acquiring recently growth. ${ }^{6}$ The matter has yet been able to answer to the rapid development of today's world, such as the emergence of aspirations and ideals that are of multi-interest and multiple dimensions that go together with various life demands and rapid technological growth. ${ }^{7}$ Moreover, education is seen as unable to respond to existing development and requirement. On the other hand, that it is always pushed aside, compared to the demands of development and needs. Furthermore, the choice for formal education institution can sometimes be threatened. Even worse, there is a growing phenomenon of educational institutions that cater to the desire for instant education. There is also a threat growing, whereby such training facilities are spreading like wild fire and the education institutions are seemingly helpless and incapable of managing education itself.

Consequently, Islamic education needs serious attention in order to achieve rightful empowerment by reviewing its current state, especially in Indonesia. This necessity, of course, will involve reviewing its relevance and role in educational endeavours of Indonesia, where Muslims are the majority, and breakthroughs such as change in implementation of model and strategies to answer to the changing times. However, in several regions such as Papua and West Papua, the Islamic community is the minority. And so, we were not able to provide justification in general because development in Islamic education also occurs in minority regions. All the while, this educational survey is more focused on locations where Muslims are the majority.

Rearrangement efforts will yield various advantages; firstly, Islamic education as the subsystem of Indonesia's national education will garner positive support and experience. Secondly, Islamic education will be able to contribute and provide an alternative to improve and better the problems, weaknesses and flaws in Indonesia's education system. Thirdly, an Islamic education system that can be developed will acquire a stronger hold in the reality of community's everyday life. ${ }^{8}$ With this development, pesantren in the form of madrasah (religious school) will be more supportive and advocative of advancing human resource.

Generally, such problems in education can happen anywhere. In the scale of the Sorong City, West Papua Province, where Muslims are minority, it is important that there be a study on how Islamic education plays a role in empowering the community.

${ }^{6}$ Ismail Suardi Wekke, "Amalan Pendidikan Bahasa Arab Berasaskan Kepelbagaian Budaya di Pesantren Provinsi Sulawesi Selatan, Indonesia," in Ringkasan Eksekutif Penyelidikan Siswazah, Jilid II, No. 2 (April 2009), p. 40 - 45.

${ }^{7}$ Latika Chaudhary and Jared Rubin, "Reading, Writing, and Religion: Institutions and Human Capital Formation," in Journal of Comparative Economics, 39 (2011), p. 17 - 33.

${ }^{8}$ A. M. Gade, "Tradition and Sentiment in Indonesian Enviromental Islam," in Worldviews: Environment, Culture and Religion, Vol. XVI, Issue 3 (2012), p. 263 - 285. 


\section{Islamic Education and Its Problems}

Islamic education is defined by the efforts put to transfer the cultural values of Islam to its young generation, and it is faced with a dichotomous question it its education system. Islamic education is observed and summarized as being stuck in its own regression, defeat, out datedness, helplessness, divide and poverty. ${ }^{9}$ The same goes with the majority of other Islamic countries and community compared to the non-Islamic counterpart. What's worse is that education with Islamic appendages have also brought about negative connotation of being old-fashioned and uninnovative, even with the gradual improvement and show of advancement in many Islamic education institutions. ${ }^{10}$

Unfortunately, this view significantly affects the Islamic education system, which ultimately, is always deemed as second class in the constellation of Indonesia's education system, even though the national education law affirmed that Islamic education is a subsystem of the national education. The seemingly inevitable predicate of out datedness and old-fashion is stuck to it, and Islamic education has often been associated with the less capable or poor population. Islamic education has had more access in the rural areas and among lower income class, whereby its cost does not burden its followers.

With such view in mind, Islamic education in today's Indonesia has not yield satisfactory impact. According to Kristiansen and Pratikno, even if it was not viewed as evidence in the past, ${ }^{11}$ there are still conclusive opinions that deem their observation as fact seeing that every time students of Islamic education participate in educational competitions among institutions, they, usually, obtain the lowest scores. The second evidence is Islamic education students' participation in the national youth scientific composition competition is still very low. ${ }^{12}$ This has been the norm for Islamic education institutions in Indonesia. Both of these measures cannot be deemed as the main parameter of out datedness for Islamic education because there are still many other factors that show Islamic education have indeed experienced development in term of its dynamics.

In the configuration of the national education system, Islamic education in Indonesia is one the variations included but in reality, it does not have a big window of opportunity to compete in developing the population at large. When considering this matter, it does seem odd that even in a community of Muslim, Islamic education is limited in its opportunity

${ }^{9}$ Risti Permani, "The Presence of Religious Organisations, Religious Attendance and Eranings: Evidence from Indonesia," in the Journal of Socio-Economics, 40 (2011), p. 247 - 258.

${ }^{10}$ Raihani, "An Indonesian Model of Succesful School Leadership," in Journal of Educational Administration, Vol. 46, No. 4 (2008), p. 481 - 496.

${ }^{11}$ Stein Kristiansen and Pratikno, "Decentralising Education in Indonesia," in International Journal of Educational Development, 26 (2006), p. 513 - 531.

${ }^{12}$ Florian Pohl, Islamic Education and Civil Society: Reflections on the Pesantren Tradition in Contemporary Indonesia," in Comparative Education Review, Vol. L, Issue 3 (August 2006), p. $389-409$. 
to empower its own people. Furthermore, the attention given by the government on Islamic education is miniscule although Indonesians have always hoped to be regarded as a religious socialistic community. ${ }^{13}$ Islamic education is seen as being a self-reliant entity in nature. So much so that even without the aid of stakeholders, Islamic education has survived and is thriving. It not being a burden instead, Islamic education has become the pride of the people amidst minimal support from education policy makers.

In general, the reality of Islamic education is acknowledged as experiencing out datedness even with the recent gradual development observed in the system. This is apparent with the establishment of various Islamic education institutions and educational models being implemented. But the challenges are still complex and demand innovation from Islamic education itself, and this is a huge and complicated task. As recently research shows, the disclosure of Islamic education's weaknesses in recent years is caused by several factors, namely weakness inmastering the system and method, language as a tool to enrich perception, interpretational accuracy, and weakness within the institution, knowledge and technology. ${ }^{14}$ Then, Islamic education is called to be more innovative, not only in relation to their curriculum and management but also it term of their operational strategies and tactics. The tactical strategies involve a revamp of both educational models and institutions, to be more effective and efficient from pedagogical, sociological and cultural perspectives in playing its role.

\section{Islamic Education Program in Indonesia}

In general, the education limits in Indonesia, according to Welch, is categorized into four main crises, namely problem in quality, relevance, elitism and management. ${ }^{15}$ Various quantitative indicators have been highlighted for the above including a comparative analysis of the education situation in various Asian countries. It is well-known that the four problems mentioned are significant problems; underlying and multidimensional in nature, finding its distinction from one another is difficult.

This crisis affects education in general, including Islamic education, which is deemed to be more problematic. Among the problems are environmental issues as global discourse within society. Therefore, according to Saniotis, the situation of today's Islamic education in Indonesia is not so different from the above generalization. The system of pesantren, which developed in the region with all its advantages, has also been overlooked and unequipped

${ }^{13}$ F. M. Mangunwijaya, "Developing Enviromental Awareness and Conservation Through Islamic Teaching," in Journal of Islamic Studies, Vol. XXII, Issue 1 (January 2011), p. 36-49.

${ }^{14}$ Ismail Suardi Wekke, "Pesantren dan Pengembangan Kurikulum Kewirausahaan: Kajian Pesantren Roudahtul Khuffadz Sorong Papua Barat," in Jurnal Inferensi, Vol. VI, No. 2 (December 2012), p. 203-226.

${ }^{15} \mathrm{~V}$. Anthony Welch, "The Limits of Regionalism in Indonesian Higher Education," in Asian Education and Development Studies, Vol. I, No. 1 (2012), p. 24-42. 
to develop the civilization. ${ }^{16}$ Considering the dilemma, an arrangement for an Islamic education model in Indonesia is very much needed. A development strategy for Islamic education needs to be chosen from the most urgent of educational activities that is central, and which will be the model foundation of future development efforts. Therefore, educational institutions such as family, school, madrasah, mosque, pesantren and other education outside of school, are still being defended.

In order to re-arrange Islamic education, we need to look back in history to the Islamic development of the $19^{\text {th }}$ century, when the Islamic world first saw the emergence of the madrasah system that caused radical changes within the system of Islamic education. The madrasah system was formally organized and it gradually overcame other more liberal education centers. The curriculum contents of the madrasah were based on the Qur'an, Hadith, fiqh and Arabic language. Other forms of knowledge that could not be learnt at the madrasah such as philosophy, chemistry, astronomy and mathematics were learnt separately and with limited means. These disciplines were placed under other subjects such as medical science. This practices not only in the majority muslim area but also at the minority conditions. ${ }^{17}$ In several models, Islamic education began teaching subjects that were also taught at regular schools. Even philosophy and logic science were included in the curriculum. The existence of such Islamic education institution significantly varied and their role and function in the national education are still being questioned. Therefore, the function of Islamic education provided at those institutions or place of learning needs to be formulated more specifically, effectively and in higher quality as to overcome the challenges that arise.

Should we examine the literature on Islamic education, we will find that the function and purpose of Islamic education is placed with more importance compared to the function of general education. The reason; the function and purpose of Islamic education are to empower or aim to help mankind to achieve happiness in this world and the hereafter. And so, its founding concept is to yield quality humans or often mentioned in the Qur'an as insan kamil (comprehensive human), with the main responsibility of managing and benefitting the earth with knowledge to achieve happiness based on a spiritual concept and move on to happiness in the hereafter. As asserted by scholars, Islamic education is capable of developing all aspects of human life that include spiritual, intellectual, imagination, and scholarly (be it individual or in groups), and it provides support and encouragement for the dynamic aspects above towards good and the fulfillment of a complete life in

${ }^{16} \mathrm{~A}$. Saniotis, "Muslim and Ecology: Fostering Islamic Enviromental Ethics," in Contemporary Islam, Vol. VI, Issue 2 (July 2012), p. 155 - 171.

${ }^{17} \mathrm{M}$. Sartawi and G. Sammut, "Negotiating British Muslim Identity: Everyday Concerns of Practising Muslim in London," in Culture and Psycology, Vol. XVIII, No. 4 (December 2012), p. 559-576. 
relation to al-Khaliq (God), with each other, as well as with the universe. ${ }^{18}$ However, from the operational point of view, these ideal formulations have yet to be fulfilled. Even with the variety of Islamic education institutions and efforts to implement those concepts, it is still lacking. In light of this, innovations or an arrangement of sort for the function of Islamic education, especially in the school system, needs to be continuously and constantly employed so that these efforts can achieve progress in the expansion and development of Islamic education system outside of school.

In addition to innovations to be made on the institution side, the factor of educators should also be improved in term of their work ethics and professionalism, improvement in the materials or contents (curriculum), which methodology is still traditionally oriented, and improvement of the education management itself. For that to happen, efforts to garner innovations must not be just to patch things up but it should start from the foundation and wholesome in nature, covering function and purpose, method, learning materials, institution of education, and its management. Meanwhile, Islamic education's function can be seen by observing its pattern in the occupational arena. This is because the job world has sufficient contribution and time period in individual and collective lives of the community. The improvement of education enables the selection of a target education model for a group of community who are less fortunate among adults. A development of vision, attitude, knowledge, skill is hoped to improve their sosio-cultural and economic life. The next target for selection is to be focused on education for children. The education and entertainment consumption of this particular group have yet to be clearly developed, except for the natural efforts passed down from time to time. ${ }^{19}$

The improvement of Islamic education's functions at the next level that should be done is to unite with other Islamic education institutions, such as mosques with their congregation, madrasah, Muslim families, Muslim community of a territory and so on. In this context, there will be at least four types of Islamic education institutions that can play out their role, namely pesantren, mosque, madrasah, and others Islamic-based education.

In this matter, Asmani placed these types of education institution, called first and second, as Islamic education institutions that can expand or improve the non-formal education system, which caters to education including various disciplines, for example, agriculture, farming, electronic, health, arts, scout, technology development, all sort of skills, and so forth. In addition, pesantren should expand their services to the community appropriately and systematically so that everything given to the community is beneficial in their daily lives and is felt Islamic in nature. The same for activities at the mosques, whereby pesantrens

\footnotetext{
${ }^{18}$ Glenn Hardaker, "An Insight Into Islamic Pedagogy at the University of al-Qarawiyyin," in Multicultural Education \& Technology Journal, Vol. VI, No. 2 (2012), p. 106-110.

${ }^{19}$ Tahir Andrabi, Jishnu Das, and Asim Ijaz Khwaja, "Students Today, Teachers Tomorrow: Identifyng Constraints on the Provision of Education," in Journal of Public Economics, 100 (2013), p. $1-14$.
} 
and mosques need to garner the collaboration of ulama (Islamic clerics) and Muslim scholars of the local colleges. In the meantime, type third and fourth, which are the madrasah education and general education, are aimed to find renovations for the formal education system that include effective teaching methods in religious or general education. These include innovations in curriculum, teaching tools, educational environment, creative and dedicated teachers, and so on. ${ }^{20}$

Truthfully, there are already Islamic education institutions that have become the favorite and popular schools among the community, even if their aspiration for Islamic schools is still considered to be low. On many levels, the underlying problem is caused by the inability of Islamic education institutions to fulfill the demands of the changing times. ${ }^{21}$ With the establishment of Madrasah Aliyah Program Khusus (MAPK - Special Program Islamic High School), which later transformed into Madrasah Aliyah Khusus (MAK-Special Islamic High School) and is categorized as a phenomenon of Islamic education excellence, is truly an asset of Islamic education that also participate in the arena of education along with other regular schools. With that said however, it has yet to profit in the national education configuration. Later, owing to the intellectuals at the Ministry of Religious Affairs, MAK was dissolved becoming a regular Madrasah Aliyah (Islamic High School).

From another perspective, there was the establishment of education outside of school for Muslim children such as TPA (Taman Pendidikan al-Qur'an - pre-elementary school in learning holy Qur'an), which emerged with new methods and techniques to ensure children can read the Qur'an in a relatively short time. ${ }^{22}$ The product of TPA became the pride of local Muslim community when their graduation was attended by a Minister and not just any minister but the President. But until today, there has yet to be a follow-up effort for this school because after graduation, the education ceased. This is also apparent in colleges of Islamic education. It seems that there is a need to broaden from a institutions that support muslim in enhancing their quality of religious activities. Not only as a formal school but also facilitate in every day activity.

The weaknesses of Islamic education as discussed above, of course, will not be further discussed, instead we should strive to carefully rectify and correct those education programs being implemented. We should work toward blurring the line that separates Islamic education with general education in the configuration of national education. The purpose and function of Islamic education, its method, material (curriculum) should be

\footnotetext{
${ }^{20} \mathrm{Apart}$ from that, the teacher must be motivated to read a lot, produce outcome, as well as becoming a figure of inspiration and motivation to students and community. See Jamal Ma'ruf Asmani, Manajemen Pengelolaan dan Kepemimpinan Pendidikan Profesional: Panduan Quality Control bagi Para Pelaku Lembaga Pendidikan (Yogyakarta: Diva Press, 2009), p. 58.

${ }^{21}$ Hery Noer Aly and Munzier S., Watak Pendidikan Islam (Jakarta Utara: Friska Agung Insani, 2003), p. 234.

${ }^{22}$ M. Suyudi, Pendidikan dalam Perspektif al-Qur'an: Integrasi Epistemologi Bayani, Burhani, dan Irfani (Yogyakarta: Mikraj, 2005), p. 15.
} 
boldly corrected and revised, and its organization (institution) improved as to attract the interest of future students without compromising the principles of Islam. ${ }^{23}$ In addition, Islamic education will once again become solid in empowering the Muslims of Indonesia, who are currently on their way to becoming an industrial population facing all kinds of challenges related to work ethics, professionalism and morals. No matter how close Islamic education is to the truth and al-Khaliq, its excellence can only be guaranteed with relentless effort. On the other hand, we shall suffer the wrath of Allah SWT. for failing Islamic education, which according to the scholars is the one and only education institution that can create balance in the development of every man and woman, whereas social development is burdened with various matters such as community change including industrialization.

\section{Islamic Education and Empowerment in West Papua}

Islamic education, in the form of madrasah has played a dynamic role in Indonesia's national education. Even during the colonization era, the pesantren produced tangible outcomes by employing efforts to develop a literate (literacy) and cultured (cultural literacy) community. ${ }^{24}$ It is all written in history as fact that in the development of pesantren, education was only one of the efforts implemented to expand its system. Therefore, we need to review the role of pesantren in the context of community empowerment.

The pesantren was developed alongside modernization, marked by the beginning of modern methods and strategies used for learning. But this does not mean westernization; instead it was the answer to the stigma and label given of being traditional. However, one renowned pesantren, Gontor, at the time when the system of pesantren was being established, was still employing traditional methods. Teaching and learning were still relying on sorogan and bandongan (method of teaching where the student has a one-to-one session with the teacher), halaqah and memorization for knowledge transference to occur. ${ }^{25}$ In the learning process at Gontor, a new method was inspired by the Dutch system of education. ${ }^{26}$ At the time, there were two models of education, whereby pesantren education was the only formal form of education that existed before the colonization. After that, in the advent of the Dutch's arrival, modern schools that employed the schooling system of Europe were introduced. ${ }^{27}$ Apart from that, the word pesantren not only meant an ineffective education

${ }^{23}$ A. Malik Fadjar, Holistika Pemikiran Pendidikan (Jakarta: RajaGrafindo Persada, 2005), p. 121.

${ }^{24} \mathrm{M}$. Sirry, "The Public Expression of Traditional Islam: The Pesantren and Civil Society in Post-Suharto Indonesia," in Muslim World, Vol. C, Issue 1 (January 2010), p. 60-77.

${ }^{25}$ Mastuhu, Dinamika Pendidikan Pesantren: Suatu Kajian tentang Unsur dan Nilai Sistem Pendidikan Pesantren (Jakarta: INIS, 1994), p. 61.

${ }^{26}$ In Abuddinnata explanation, Islamic education in Indonesia began adopting learning methods employed by the Dutch since 1906. Abudinnata, Tokoh-tokoh Pembaharuan Pendidikan Islam di Indonesia (Jakarta: RajaGrafindo Persada, 2005) p. 12.

${ }^{27}$ Potoceanu Nadia, Gillich Nicoleta, Rada Doina, and Hamat Codruta, "Some Contributions 
system but it also brought about meaning of static thinking. By attaching the word modern in Gontor's education system, it was articulated as freedom to think, effective and efficient management, and the introduction of modernism to the students. ${ }^{28}$

And so, the pesantren no longer depended on just following (taqlid) certain sect, it was encouraged to think for themselves. Meanwhile, effective and efficient management were implemented in the form of transparent and accountable handling of the pesantren's finance and administration. This also included the top management not focusing only on certain individuals and kiyai families but on the pesantren as a whole Badan Waqaf (a body of religious endowment). The previous ownership of kiyai and families were fully handed over to the institution in the form of badan waqaf.

In the opinion of one Greg Barton ${ }^{29}$, Islamic education like Gontor is an educational institution that successfully combined the learning requirement of classical Islamic knowledge with modern approach. The use of a teaching system for Islamic subjects made it possible for students to not be trapped in the past and become out-of-date in order to compete in current times. Furthermore, with the integration of current teaching methodologies into inherited Islamic knowledge, a comprehensive education institution was born and it became an important solution to the Muslims' education. During those times, Islamic education institutions were limited to teaching classical Islamic knowledge by using traditional methods. Eventhough, there were several pesantrens bold enough to adopt the education styles employed at the colonial schools of the Dutch. Teaching materials maintained their traditional Islamic values, whereby emphasis was given to mastering the holy books, but the method of delivery utilized a modern strategy.

If we look further into history, it is obvious that the pesantren took devotion of efforts in the domain of education. This paper will attempt to address how the role played by the pesantren is related to community empowerment. Data presented in the paper was obtained from the Pesantren Roudhatul Khuffadz, Sorong, Papua Barat.

\section{Islamic Education in Minority Muslim}

Studies on Islamic education have obtained special attention from scholars. Even so, the focus given is still limited to the type of Islamic education in Muslim majority areas and where it is considered to be mainstream education. Studies and publication on education

to the Developmentof Education Projects in European Area," in Procedia Social and Behavioral Science, 1 (2009), p. 2390-2395.

${ }^{28}$ Panitia Penyusunan Riwayat Hidup dan Perjuangan K.H. Imam Zarkasyi, Biografi K.H. Imam Zarkasyi: Dari Gontor Merintis Pondok Modern (Ponorogo: Gontor Press, 1996).

${ }^{29}$ Greg Barton, Gagasan Islam Liberal di Indonesia, Pemikiran Neo-Modernisme Nurcholish Madjid, Djohan Effendi, Ahmad Wahib, dan Abdurrahman Wahid, 1968-1980, transl. Nanang Tahqiq (Jakarta: Paramadina, 1999), p. 75-77. 
in Muslim minority areas are lacking. For that reason, this paper attempts to discuss Islamic education in minority area. The existence of Islamic education in areas such as Sorongbe it at the municipal level or regency, have not only strengthened the religious identity but also has become a statement of religion for the Indonesian people. In term of identity, as insisted by Lily Kong ${ }^{30}$, being a minority has encouraged them to defend their identity to the majority, but in the context of religion in Indonesia, while Muslims in other municipalities enjoy the freedom to practice their religion because of their significant number, the Muslims of Sorong Raya enjoy freedom of religion because of their status as the minority. Not because of the religion they believe in but due to their courage to be different from other Papuans.

In the meantime, the segregation that occur in other parts of the world, where there are minority Muslims, has not occurred in every day community life in Papua, Sorong Raya. If we compare to the situation in Thailand, ${ }^{31}$ where the Malay ethnic people are isolated and prohibited to openly show their identity, the life of the Sorong community involves no segregation. This may be because of the local minority status but the majority at the national level factor. Although sometimes the ethnicity of Papuans is considered to be different from Indonesians in general, ever since 2001, this perspective has waned down. ${ }^{32}$ During the New Order, according to Aspinnal and Berger, ${ }^{33}$ a primordial sentiment began to form and it implied a choice for independence, which became a purpose that could not be faded.

The pesantren in the city of Sorong has significantly contributed as an institution that advocates harmony in social interaction between different religions and ethnicity ${ }^{34}$. Mujahidah's observation shows the presence of Islamic education institutions is catalytic as well as supporter of capacity among students to defend the existing harmony through interaction, which not only involve social relations but also helping each other out in religious activities. In the context of Sorong, the phenomenon of cooperation is not alien, even in a community of different ethnicity, religion and other social status. With the interaction that goes on, however, they may be boundaries that differentiate the group in social relation. ${ }^{35}$

${ }^{30}$ Lily Kong, "Cultural Icons and Urban Development in Asia: Economic Imperative, National Identity, and Global City Status", in Political Geography, 26 (2007), p. 383 - 404.

${ }^{31}$ Azam Othman and Natyada Wanlabeh, "Teachers' Perspectives on Leadership Practices and Motivation in Islamic Private Schools, Southern Thailand," in Asian Education and Development Studies, Vol. I, No. 3, (2012), p. 237 - 250.

${ }^{32}$ Syafuan Rozi, "Nasionalisme, Demokratisasi, dan Sentimen Primordialisme di Indonesia: Problematika Identitas Keetnisan versus Keindonesiaan pada Studi kasus Aceh, Papua, Bali, dan Riau," in Jurnal Penelitian Politik, 6, 1 (2009), p. 75-84.

${ }^{33} \mathrm{E}$. Aspinall and M. T. Berger, "The Break Up of Indonesia? Nationalism after Decolonisation and the Limits of the Nation-State in Post-Cold War Southeast Asia," in Third World Quarterly, 22, 6, (2001), p. 139-169.

${ }^{34}$ Mujahidah, Analisis Terhadap Interaksi Sosial Antar Pemeluk Agama dan Etnis di Kota Sorong (Sorong: Pustaka Rafana, 2010), p. 61.

${ }^{35} \mathrm{He}$ An E, "Bridging the Gap Between Teacher Educator and Teacher in a Community of Practice: A Case of Brokering," in System, 37, (2009), p. 153 - 163. 
Considering the interaction pattern mentioned above, it is vital that there would be identity awareness. Such identification is important to individuals in relation to the situation within a community. ${ }^{36}$ Individuals are no longer considered to be merely personal beings but they are members of the society. ${ }^{37}$ Therefore, it is crucial for the pesantren as an education institution to provide a scene for formal socialization to occur according to the interaction and behavior patterns of a multiracial community without surrendering religious identity. Even if the perfect portrait of Papua's education is still far from realization, ${ }^{38}$ the establishment of Pesantren Roudatul Khuffadz will be the pioneer and beacon among the community. The educational service provided will be close to the Muslims of Papua, developed and implemented for them. It not only provides education in formal form but it goes beyond to strengthen the skills of Muslims. In the midst of limits to education access and presumptions, the existence of this pesantren has gained a special place.

If we look at the history in Europe, ethnic identity, religion, class, skin color far exceeded against the identity of a nation-state. ${ }^{39}$ The fate of minority does not necessarily mean isolation and limited access to politics because, according to Azyumardi Azra, the process that the minority group goes through is not one and identical. ${ }^{40}$ There has been minority Muslims in several provinces that underwent dynamic national processes.

\section{Community Empowerment and Pesantren}

One cause of poverty, as stated de Noble, is the subsistence of structural poverty due to agricultural land polarization. ${ }^{41}$ Then, empowering agricultural management will lessen the potential of poverty. The selection of agriculture as a means for food management will address the utmost important matter in poverty itself, which is to manage food requirement. This will ultimately allow the community to overcome the problem by addressing individual needs. However, empowerment efforts are not exclusive to land management. There is also a need for skills in understanding technology, whereby technological transfer to rural

\footnotetext{
${ }^{36}$ Yisrael Rich and Elli P. Schachter, "High School Identity Climate and Student Identity Development," in Contemporary Educational Psychology, 37 (2012), p. 218 - 228.

${ }^{37}$ Craig S. Galbraith and Devon M. Galbraith, "An Empirical Note on Entrepreneurial Activity, Intrinsic Religiosity and Economic Growth," in Journal of Enterprising Communities: People and Places in the Global Economy, Vol. I, No. 2 (2007), p. 188 - 201.

${ }^{38} \mathrm{Ahm}$ ad Arif dan Luki Aulia, "Frederick Sitaung, Guru Sejati di Papua," in Kompas (1 September 2007).

${ }^{39}$ Wanda Alberts, Integrative Religious Education in Europe: A Study of Religions Approach (Berlin-New York: Walter de Gruyter, 2007), p. 42.

${ }^{40}$ Azyumardi Azra, "Discourse on Minority Muslims," in M. Ali Kettani, Minoritas Muslim di Dunia Dewasa Ini (Jakarta: Rajawali Pers, 2005), p. xxv.

${ }^{41}$ Alex de Noble, "Market Juctice, Religious Orientation and Entrepreneurial Attitudes An Empirical Study," in Journal of Entreprising Communities People and Places in The Global, Vol. I, No. 2 (2007), p. 121 - 134.
} 
areas is hoped to, later, increase the local well-being. ${ }^{42}$ For this, there is one empowerment program that was successfully implemented in the rural area. The rural empowerment program as the community's main group is one of the means to empower the community. ${ }^{43}$ This perspective is relevant in a country where the majority of its population lives in the rural areas such as Indonesia. It is the rural area that supplies the food to the cities. Should development and empowerment cease in the countryside, the cities will indeed lose its support to continue to grow.

The pesantren has grown and progressed in rural environment. Its establishment in these rural areas has significantly affected the growth of local community. Not only in term of religious understanding but also in term of the community's life and skills. ${ }^{44}$ Even though it is famous for its traditionalism, the pesantren has become a beacon of light in society. With activities that revolve around education, the pesantren has enlightened the mindset of society, which was later termed as the renewal of mindset. This ultimately caused an increase in human resource. As a basis for culture in rural areas, the pesantren has become the driving force for quality in human resource. This will of course become an agent of change in the community. ${ }^{45}$ The pesantren also provides support for skill acquirement in the form of vocational education, even though still limited to co-op and animal farming. By managing the co-op in turns, students will be able to obtain the ability to manage an organization or company for economic interest. This will indirectly train them and provide experience with hands-on skills by instilling a sense of responsibility in them to conduct business. ${ }^{46}$

The development of IPTEK (knowledge and technology) outside of the pesantren is a rapid one and so, the pesantren must also accelerate in the area of knowledge and technology. The pesantren is responsible to adapt the culture that is most suitable with the nature and values of the pesantren community. And this will then make the socio-cultural aspect of the pesantren an important factor in improving human resource (SDM). ${ }^{47}$ The pesantren is multidimensional in nature. It is resilient against change, with the exception that the change is drafted by the pesantren itself, which then will emerge a dynamic and positive

${ }^{42}$ M. A. Lubis, M. A. Embi, M. Md. Yunus, I. S. Wekke, and N. M. Nordin, "The Application of Multicultural Education and Applying ICT on Pesantren in South Sulawesi, Indonesia," in WSEAS Transactions on Information Science and Applications, Vol. VI, Issue 8, (2009), p. 14011411.

${ }^{43}$ Gunawan Sumodiningrat, Pemberdayaan Sosial: Kajian Ringkas tentang Pembangunan Manusia Indonesia (Jakarta: Penerbit Buku Kompas, 2007), p. xv.

${ }^{44}$ Abd. A'la, Pembaruan Pesantren (Yogyakarta: Pustaka Pesantren, 2006), p. 1-2.

${ }^{45}$ Rofiq. A, et al., Pemberdayaan Pesantren (Yogyakarta: Pustaka Pesantren, 2005), p. xii-xiii.

${ }^{46}$. Nilan, "The 'Spirit of Education' in Indonesian Pesantren," in British Journal of Sociology of Education, Vol. 30, Issue 2 (March 2009), p. 219 - 232.

${ }^{47} \mathrm{H}$. Sonhadji Sholeh, Konsep-konsep Pengembangan SDM, in A. Halim, et al. (ed.), Manajemen Pesantren (Yogyakarta: Pustaka Pesantren, 2005), p. 7. 
revival for the development of the pesantren. ${ }^{48}$ In history, the pesantren has contributed a lot in Indonesia's national development. ${ }^{49}$ Elements within the pesantren itself made it possible for high level of participation in development. ${ }^{50}$ Florian Pohl shows that the pesantren is where humanistic values and social justice is nurtured. ${ }^{51}$ With that sad, the pesantren's role can be expanded into empowerment of life. This includes providing students with the tools and skills needed for managing a farming organization.

In short, the existence of pesantren in rural areas will indeed empower the local environment. The pesantren itself has undergone a significant metamorphosis, ${ }^{52}$ suitable for their survival and subsistence. Adaptability toward local environment makes the pesantren more valuable in the eyes of the community. It is based on this that an observation related to community empowerment through agriculture becomes important. How does the pesantren manage their potential to provide relevant skills to their students? Why, for all this time, the pesantren has been identified with only religious education? From another aspect, the pesantren has begun creating local potential and its role can be further maximized.

\section{Pesantren Roudhatul Khuffadz Sorong}

The Pesantren Roudhatul Khuffadz is located in Aimas, the capital of Sorong regency. The pesantren holds diniyah (religious learning material) classes in the afternoon (after Ashr pray) that continues until night (after Isha pray). While formal education provided is still limited to madrasah ibtidaiyah (elementary school) and in 2011, it was their first graduation. The students living at the pesantren come from various regions in West Papua. During their stay at the pesantren's dormitory, they still attend formal education at the nearest school especially those in high school. In the meantime, students of elementary school age attend classes at the madrasah ibtidaiyah, which is located within the pesantren's campus.

In the afternoon, students return from school and rest, and after that, they attend classes in the form of halaqah guided by the pesantren's elders. At night, they attend classes that are appropriate to the curriculum of madrasah diniyah. During weekend or school holidays, students are assigned activities that interest them and according to their

${ }^{48}$ Raihani, "Report on Multicultural Education in Pesantren," in Compare, Vol. XXXXII, Issue 4 (July 2012), p. $585-605$.

${ }^{49}$ D. Izfanna and N. A. Hisyam, "A Comprehensive Approach in Developing Akhlaq: A Case Study on the Implementation of Character Education at Pondok Pesantren Darunnajah," in Multicultural Education and Technology Journal, Vol. VI, Issue 2 (June 2012), p. 77 - 86.

${ }^{50}$ Abdullah Syukri Zarkasyi, Gontor \& Pembaharuan Pendidikan Pesantren (Jakarta: RajaGrafindo Persada, 2005), p. 4.

${ }^{51}$ Florian Pohl, "Interreligious Harmony and Peacebuilding in Indonesian Islamic Education," in Cristina Jayme Montiel \& Noraini N. Noor (ed.), Peace Psychology in Asia (London: Springer Science+Business Media, 2009), p. 147.

${ }^{52} \mathrm{M}$. Amin Haedari, Transformasi Pesantren: Pengembangan Aspek Pendidikan, Keagamaan, dan Sosial (Jakarta: LeKDiS, 2006) p. 50. 
own capability. As mentioned by Kiyai Yasin, "students are assigned into groups according to their interest and capability. If the student is at elementary school age, then they will be tasked with feeding the farm animals. But if they're of high school age, they will then be tasked with taking care of the farm animals." ${ }^{53}$

In the surrounding area of the pesantren, various pieces of land are available and they are managed by the students themselves. In the compound, there are chicken farming, cattle farming, ducks, as well as short-term crops such as chilies, tomatoes and other catch crops such as corn. Other than that, there is a need to supply fodder for the livestock and so there is Napier grass. There is also inter-cropping for chicken farming, which is combined with an embankment for catfish, and around the mosque at the wudhu' (ablution) area, used ablution water is collected into a pond of tilapia. By providing opportunity for the students to learn hands-on, their skills will be honed and they will not just learn from theories. In the meantime, should there be a mistake while carrying out practical activities in the field, theory of the correct way will be directly explained. As with instructions and guidance from the kiyai and elders at the pesantren, there will be given at certain times during the day. The part for theory is kept at a minimum and when compared, practical activities in the field very much dominate the process of learning. And so Kiyai Yasin explained:

By giving the chance for interaction and experience to learn, the students will be able to focus more and make their own conclusion of their recurring experiences. As an education process, this will indirectly become a way of completely not giving theoretical instructions but to learn directly from experience. If this is nurtured, students will retain more memory permanently and for a long time, compared to just by lecturing in classes. ${ }^{54}$

Agriculture and farming was chosen as the focus of learning because it has the natural potential in Papua, which is dominated by its vast land. With agriculture, comes animal farming. Equipped with that they learn at the pesantren, students will continue to live in the outside world with skills that are not far from reality. And so they will not be estranged and become a useful member of society. Agriculture and animal farming is an important requirement for the community in Sorong, whereby several grocery items need to be imported or shipped from other areas. With the skill to manage agricultural land, surely the community is provided for and can become self-reliant. The internal production of grocery items can easily compete with imported products. Furthermore, this skill acts as a supplement to the more crucial capacity that is religious knowledge, which should also be taught to the community. At the very least, religious knowledge and skills obtained at the pesantren can be used by individuals to teach their own little cluster called family.

\footnotetext{
${ }^{53}$ Interview with the leader at Pesantren Roudhatul Khuffadz, on April 12, 2011. In effort to data enhacement interview and observation were extended from June to December 2012.

${ }^{54}$ This initial data was collected first time on interview with Kiyai Yasin, March 8, 2011. Data validation was employed on November and December 2012.
} 
Guidance in religious capacity is of the utmost importance, while skills are complimentary and enriching. When students return to society, their skills will become their communication tools to complement their daily lives. In addition, pesantren alumni are also called to become the driving force for religious activities in their respective community in a place where Muslims are the minority and religious understanding is very limited, especially for a newly converted Muslim. In turn, pesantren alumni will also become the preacher in their hometown. This is so by being a good example and show that a pesantren alumnus is not only capable at the mosque's rostrum but more importantly, he has the skills to manage the community's potential. With that, the face of Islam is sound and dominant compared to just being a person who can start a discourse and discussion. Consequently, sympathy and desire to socialize with the Muslim community will be generated.

This depiction shows that a pesantren alumnus can indeed carry out his responsibilities as caliphs on this earth. He is no longer a burden to his family and community but instead, a pioneer for the growth of his family and environment. Not only limited to Muslims but others around him, whereby they live in a community where Muslims are not the majority, and to grow and progress together with followers of other religions. Equipped with the knowledge and skills learnt at the pesantren, the alumnus possesses the foundation for creative process to implement at his hometown. As the number of alumni grows, all spread out in different areas of the region, surely it would be the making of community empowerment.

The learning experience gained at Pesantren Roudhatul Khuffadz is, in actual fact, a form of effort to provide freedom to each and every student in learning skills related to livestock farming and agriculture day by day. This supplementary activity is planned to hone students' ability in mastering various skills. As soon as they are free to choose their activities, then that is the moment they contribute to their self-growth. Finally, once they are able to develop themselves, surely they will be more than able to help the community around them grow in capacity too.

\section{Theoretical Implications}

The pesantren has provided a lot of effort, not only in the field of education but it has also begun reinforcing the empowerment of the community. The skills taught at the pesantren are not limited to religious knowledge but includes skills in agriculture. The study on Pesantren Roudhatul Khuffadz has yielded proof that a pesantren can indeed bring about transformation at all levels of the community. This corresponds to the theory presented Maldonado, Khan, Moon, and Rho in term of education and developing countries, which depicts a pesantren as social influence in on the rise of societies. The advent of modern technology, joined by the discussion of globalization, has brought about dynamic trans- 
formation that affects the very existence of educational system. ${ }^{55}$ Encounter with modern values is, in the view of Yasmadi, ${ }^{56}$ a dynamic development, which ultimately solidifies the pesantren's existence. Such transformation will propel the pesantren intro progress and establish its position within the community.

Then, the religious education institution will no longer be just a topic for discourse but becomes more of a spiritual awareness that also emphasizes the need to hone various skills in order to influence the behavior of society. ${ }^{57}$ This proves that the existence of pesantren in the past has never been overlooked by those around it. In addition, the growth of a pesantren begins with an observation of it surrounding condition. This is due to the fact that with pesantren's development, only then a synergy can occur with the environment - the community at large can become partners with the pesantren to develop each other. Another research was conducted in this pesantren. The study was concluded that Pesantren Roudhatul Khuffadz tried to enhance students' capacity through entrepreneurship. ${ }^{58}$

One of the main problems of education is the irrelevancy of the contents in the working world. It has often been the case where formal education graduates are unqualified to compete in the job market that relies on skills. In the words Steenkamp and McCord, education is unable to respond to and anticipate the needs of the community in working matters. It is a need to maintain media and information technology. ${ }^{59}$ There is no creativity among education institutions to bridge the gap that exists. Therefore, the findings of this paper, Pesantren Roudhatul Khuffadz does indeed polish students' skills to farm, prove that the generalization of education institutions' inability to provide sound curriculum in order to anticipate the working world has yet to be supported completely. The pesantren actively equips students to become entrepreneurs in the field of agriculture. Pesantren alumni are found able to develop themselves in modern agriculture. This may be because a lot of the land in Papua has yet to be developed and this is indeed valuable to students who are about to dive into the community.

In the context of Pesantren Roudhatul Khuffadz, the process of education has become a process of transfer in several matters, namely knowledge, values and skills. Education

${ }^{55}$ Ursula Paola Torres Maldonado, Gohar Feroz Khan, Junghoon Moon, and Jae Jeung Rho, "E-Learning Motivation and Educational Portal Acceptance in Developing Countries," in Online Information Review, Vol. XXXV, No. 1 (2011), p. 66 - 85.

${ }^{56}$ Yasmadi, Modernisasi Pesantren (Jakarta: Ciputat Press, 2005), p. 3.

${ }^{57} \mathrm{~N}$. van Der Straten Waillet and I. Roskam, "Are Religious Tolerance and Pluralism Reachable Ideals? A Psychologhical Perspective," in Religious Education, Vol. CVIII, Issue 1 (2013), p. $69-87$.

${ }^{58}$ Ismail Suardi Wekke, "Pendidikan Islam dan Pemberdayaan Masyarakat (Tinjauan Pendidikan Vokasional Pesantren Roudhatul Khuffadz, Sorong)," in Jurnal Kajian Islam Interdisipliner Hermenia, Vol. X, No. 1 (December 2011), p. 23 - 53.

${ }^{59}$ Annette Lerine Steenkamp and Samual Alan McCord, "Approach to Teaching Research Methodology for Information Technology," in Journal of Information Systems Education, 18, 2, (Summer 2007), p. $255-266$. 
that empowers is education that will not only provide cognitive knowledge but goes further to provide skills as useful tools to illustrate the knowledge obtained. The findings of this study correspond to the theory presented by Haidar Putra Daulay that states the process of education cannot only be given in the formal form. ${ }^{60}$ Education can also be defined as the process of understanding. Therefore, the installation of values in the form of skills can in fact be the actual content of the education itself. Only the form is informal and its delivery is performed outside of the classroom. Finally, such processes will be more meaningful and provide better and comprehensive understanding to the students.

\section{Conclusion}

Based the above discussion, it can be concluded that the crisis of Islamic education is not mere discussion but it is indeed a problem to be solved. The separation of Islamic education from general education in the configuration of national education can be overcome. Islamic education has become the catalyst and has answered various criticisms that a pesantren is where the seed of terrorism is sowed. The purpose and function of Islamic education, its method, materials (curriculum) must be corrected and revised boldly and its organization (institution) must be improved. With such efforts, Islamic education can once again return to its true position in empowering the Muslims of Indonesia, who are gearing toward becoming an industrial population faced with all sort of challenges including work ethics, professionalism and morals. Simultaneously, distancing Islamic education from discussions of dichotomic education, whereby there no longer exist a line between Islamic education and general education, and that both are the same.

The implementations at Pesantren Roudhatul Khuffadz have proven that even being in an area where Muslims are the minority, the pesantren can still prosper. By being the minority, Islamic identity is felt stronger and this ultimately will become the supporting force that contributes to the development of local education.

\section{References}

A, Rofiq. et al. Pemberdayaan Pesantren. Yogyakarta: Pustaka Pesantren, 2005.

A’la, Abd. Pembaruan Pesantren. Yogyakarta: Pustaka Pesantren, 2006.

Alberts, Wanda. Integrative Religious Education in Europe: A Study-of-Religions Approach. Berlin-New York: Walter de Gruyter, 2007.

Aly, Hery Noer and S, Munzier. Watak Pendidikan Islam. Jakarta Utara: Friska Agung Insani, 2003.

${ }^{60}$ Haidar Putra Daulay, Sejarah Pertumbuhan dan Pembaruan Pendidikan Islam di Indonesia (Jakarta: Prenada Media Group, 2007), p. 13-14. 
Andrabi, Tahir., Das, Jishnu., and Khwaja, Asim Ijaz. "Students Today, Teachers Tomorrow: Identifyng Constraints on the Provision of Education," in Journal of Public Economics, 100, 2013.

Arif, Ahmad., and Aulia, Luki. "Frederick Sitaung, Guru Sejati di Papua," in Kompas, 1 September 2007.

Arifin, Anwar. Format Baru Pengelolaan Pendidikan. Jakarta: Pustaka Indonesia, 2006.

Asmani, Jamal Ma'ruf. Manajemen Pengelolaan dan Kepemimpinan Pendidikan Profesional: Panduan Quality Control bagi Para Pelaku Lembaga Pendidikan. Yogyakarta: Diva Press, 2009.

Aspinall, E., and Berger, M. T. "The Break Up of Indonesia? Nationalism after Decolonisation and the Limits of the Nation-State in Post-Cold War Southeast Asia," in Third World Quarterly, 22, 6, 2001.

Azra, Azyumardi. "Discourse on Minority Muslims, Introduction," in M. Ali Kettani, Minoritas Muslim di Dunia Dewasa Ini. Jakarta: Rajawali Pers, 2005.

Barton, Greg. Gagasan Islam Liberal di Indonesia, Pemikiran Neo-Modernisme Nurcholish Madjid, Djohan Efendi, Ahmad Wahib, dan Abdurrahman Wahid, 1968-1980, transl. Nanang Tahqiq. Jakarta: Paramadina, 1999.

Chaudhary, Latika., and Rubin, Jared. "Reading, Writing, and Religion: Institutions and Human Capital Formation," in Journal of Comparative Economics, 39, 2011.

Daulay, Haidar Putra. Sejarah Pertumbuhan dan Pembaruan Pendidikan Islam di Indonesia. Jakarta: Prenada Media Group, 2007.

E, He A. "Bridging the Gap between Teacher Educator and Teacher in a Community of Practice: A Case of Brokering," in System, 37, 2009.

Elyas, Tariq., and Picard, Michelle. "Saudi Arabian Educational Historu: Impacts on English Language Teaching," in Education, Business and Society: Contemporary Middle Eastern Issues, Vol. III, No. 2, 2010.

Fadjar, A. Malik. Holistika Pemikiran Pendidikan, Jakarta: RajaGrafindo Persada, 2005.

Gade, A. M. "Tradition and Sentiment in Indonesian Enviromental Islam," in Worldviews: Environment, Culture and Religion, Vol. XVI, Issue 3, 2012.

Galbraith, Craig S., and Galbraith, Devon M. "An Empirical Note on Entrepreneurial Activity, Intrinsic Religiosity and Economic Growth," in Journal of Enterprising Communities: People and Places in the Global Economy, Vol. I, No. 2, 2007.

Genç, M. Fatih. Avest, Ina ter., and Miedema, Siebren. "Religious education in two secular multicultural societies: the Turkish and Dutch case compared," in Procedia Social and Behavioral Sciences, 15, 2011.

Haedari, M. Amin. Transformasi Pesantren: Pengembangan Aspek Pendidikan, Keagamaan, dan Sosial. Jakarta: LeKDiS, 2006.

Hardaker, Glenn. "An Insight Into Islamic Pedagogy at the University of al-Qarawiyyin," in Multicultural Education \& Technology Journal, Vol. VI, No. 2, 2012. 
Izfanna, D., and Hisyam, N. A. "A Comprehensive Approach in Developing Akhlaq: A Case Study on the Implementation of Character Education at Pondok Pesantren Darunnajah," in Multicultural Education and Technology Journal, Vol. VI, Issue 2, June 2012.

Kong, Lily. "Cultural Icons and Urban Development in Asia: Economic Imperative, National Identity, and Global City Status," in Political Geography, 26, 2007.

Kristiansen, Stein., and Pratikno, "Decentralising Education in Indonesia," in International Journal of Educational Development, 26, 2006.

Lubis, M. A., Embi, M. A., Yunus, M. Md., Wekke, I. S., and Nordin, N. M. “The Application of Multicultural Education and Applying ICT on Pesantren in South Sulawesi, Indonesia," in WSEAS Transactions on Information Science and Applications, Vol. VI, Issue 8, 2009.

Maldonado, Ursula Paola Torres. Khan, Gohar Feroz. Moon, Junghoon., and Rho, Jae Jeung. "E-Learning Motivation and Educational Portal Acceptance in Developing Countries," in Online Information Review, Vol. XXXV, No. 1, 2011.

Mangunjaya, F. M. "Developing Enviromental Awareness and Conservation Through Islamic Teaching,” in Journal of Islamic Studies, Vol. XXII, Issue 1, January 2011.

Mastuhu. Dinamika Pendidikan Pesantren: Suatu Kajian tentang Unsur dan Nilai Sistem Pendidikan Pesantren. Jakarta: INIS, 1994.

Muhaimin. Pengembangan Kurikulum Pendidikan Agama Islam: di Sekolah, Madrasah, dan Perguruan Tinggi. Jakarta: RajaGrafindo Persada, 2005.

Mujahidah. Analisis Terhadap Interaksi Sosial Antar Pemeluk Agama dan Etnis di Kota Sorong. Sorong: Pustaka Rafana, 2010.

Nadia, Potoceanu., Nicoleta, Gillich., Doina, Rada., and Codruta, Hamat. "Some Contributions to the Developmentof Education Projects in European Area," in Procedia Social and Behavioral Science, 1, 2009.

Nata, Abudien. Tokoh-tokoh Pembaharuan Pendidikan Islam di Indonesia. Jakarta: Raja Grafindo Persada, 2005.

Nilan, P. "The 'Spirit of Education' in Indonesian Pesantren," in British Journal of Sociology of Education, Vol. XXX, Issue 2, March 2009.

Noble, Alex de. "Market Juctice, Religious Orientation and Entrepreneurial Attitudes An Empirical Study," in Journal of Entreprising Communities People and Places in The Global, Vol. I, No. 2, 2007.

Othman, Azam., and Wanlabeh, Natyada. "Teachers' Perspectives on Leadership Practices and Motivation in Islamic Private Schools, Southern Thailand," in Asian Education and Development Studies, Vol. I, No. 3, 2012.

Panitia Penyusunan Riwayat Hidup dan Perjuangan K.H. Imam Zarkasyi. Biografi K.H. Imam Zarkasyi: Dari Gontor Merintis Pondok Modern. Ponorogo: Gontor Press, 1996.

Permani, Risti. "The Presence of Religious Organisations, Religious Attendance and Eranings: Evidence from Indonesia," in The Journal of Socio-Economics, 40, 2011. 
Pohl, Florian. "Interreligious Harmony and Peacebuilding in Indonesian Islamic Education," in Cristina Jayme Montiel \& Noraini N. Noor (ed.), Peace Psychology in Asia. London: Springer Science+Business Media, 2009.

Pohl, Florian. "Islamic Education and Civil Society: Reflections on the Pesantren Tradition in Contemporary Indonesia," in Comparative Education Review, Vol. 50, Issue 3, August 2006.

Raihani. "An Indonesian Model of Succesful School Leadership," in Journal of Educational Administration, Vol. XLVI, No. 4, 2008.

Raihani. "Report on Multicultural Education in Pesantren," in Compare, Vol. XLI, Issue 4, July 2012.

Rich, Yisrael, and Schachter, Elli P. "High School Identity Climate and Student Identity Development," in Contemporary Educational Psychology, 37, 2012.

Rozi, Syafuan. "Nasionalisme, Demokratisasi, dan Sentimen Primordialisme di Indonesia: Problematika Identitas Keetnisan versus Keindonesiaan pada Studi Kasus Aceh, Papua, Bali, dan Riau," in Jurnal Penelitian Politik, 6, 1, 2009.

Saniotis, A. "Muslim and Ecology: Fostering Islamic Enviromental Ethics," in Contemporary Islam, Vol. VI, Issue 2, July 2012.

Sartawi, M., and Sammut, G. "Negotiating British Muslim Identity: Everyday Concerns of Practising Muslim in London," in Culture and Psycology, Vol. XVIII, No. 4, December 2012.

Sholeh, H. Sonhadji. "Konsep-konsep Pengembangan SDM," in A. Halim, et al., Manajemen Pesantren. Yogyakarta: Pustaka Pesantren, 2005.

Sirry, M. "The Public Expression of Traditional Islam: The Pesantren and Civil Society in Post-Suharto Indonesia," in Muslim World, Vol. 100, Issue 1, January 2010.

Steenkamp, Annette Lerine., and McCord, Samual Alan. "Approach to Teaching Research Methodology for Information Technology," in Journal of Information Systems Education, 18, 2, Summer 2007.

Sumodiningrat, Gunawan. Pemberdayaan Sosial: Kajian Ringkas Tentang Pembangunan Manusia Indonesia. Jakarta: Penerbit Buku Kompas, 2007.

Suyudi, M.. Pendidikan dalam Perspektifal-Qur'an Integrasi Epistemologi Bayani, Burhani, dan Irfani. Yogyakarta: Mikraj, 2005.

Waillet, N. van Der Straten, and Roskam, I. "Are Religious Tolerance and Pluralism Reachable Ideals? A Psychologhical Perspective." in Religious Education, Vol. 108, Issue 1, 2013.

Wang, Qiyun. "A Generic Model for Guiding the Integration of ICT into Teaching and Learning," in Innovations in Education and Teaching International, Vol. XLV, No. 4, November 2008.

Wekke, Ismail Suardi. "Amalan Pendidikan Bahasa Arab Berasaskan Kepelbagaian Budaya di Pesantren Provinsi Sulawesi Selatan, Indonesia," in Ringkasan Eksekutif Penyelidikan Siswazah, Jilid. 2, No. 2, April 2009. 
Wekke, Ismail Suardi. "Pesantren dan Pengembangan Kurikulum Kewirausahaan: Kajian Pesantren Roudahtul Khuffadz Sorong Papua Barat," in Jurnal Inferensi, Vol. 6, No. 2, December 2012.

Wekke, Ismail Suardi. "Pendidikan Islam dan Pemberdayaan Masyarakat (Tinjauan Pendidikan Vokasional Pesantren Roudhatul Khuffadz, Sorong)," in Jurnal Kajian Islam Interdisipliner Hermenia, Vol. 10, No. 1, December 2011.

Welch, V. Anthony. "The Limits of Regionalism in Indonesian Higher Education," in Asian Education and Development Studies, Vol. 1, No. 1, 2012.

Yasmadi. Modernisasi Pesantren. Jakarta: Ciputat Press, 2005.

Zarkasyi, Abdullah Syukri. Gontor \& Pembaharuan Pendidikan Pesantren. Jakarta: Raja Grafindo Persada, 2005. 